Pekan 2

\title{
Penelitian Studi Islam: Membedakan Keagaman dan Pendidikan Keagamaan
}

\author{
Ismail Suardi Wekke \\ Pascasarjana Institut Agama Islam negeri (IAIN) Sorong \\ Email: iswekke@gmail.com
}

\section{Pendahuluan}

Penelitian agama dan penelitian keagamaan, dua hal yang berbeda. Jikalau itu penelitian agama, maka sudah ada "pakem"-nya yaitu penelitian tafsir, penelitian hadis dst.

Sementara penelitian keagamaan, bisa menggunakan pelbagai ragam metode yang sudah ada. agama sebagai gejala sosial (Mudzhar, 1998).

Cak Nur membedakannya dengan istilah doktrin dan peradaban (Madjid, 1992). Sementara Abdullah (1996) menyebutnya dengan normativitas historisitas. Adapun Mathar (2007) mengemukakan dengan istilah Islam wahyu dan Islam budaya.

Ringkasnya dapat dikemukakan bahwa sebagai wahyu, Islam merupakan sebuah kebenaran yang mutlak. Sementara aspek keberagamaan yang memungkinkan untuk diteliti (Wekke, 2020). Demikian pula untuk melihat masa depan kajian Islam di Indonesia (Wekke, 2018).

\section{Darimana Memulai?}

Pertama yang harus diperhatikan ada sebuah fakta atau fenomena. Bukan harapan atau hanya melihat sebab-akibat.

Sebagai contoh, di Papua ada organisasi yang bernama Yapis. Maka, ini bisa dilihat bagaimana kondisi faktual Yapis. Setelah mengamati keberadaan Yapis, maka dilakukan konfirmasi literatur.

Dengan "menggali" literatur yang ada, maka dapat ditemukan masalah penelitian yang belum memiliki jawaban. Kalau sudah ada jawaban, dan "hipotesa" yang menjadi alur penelitian kita sudah duga hasilnya, maka tinggalkan pertanyaan yang sudah kita ajukan dengan menemukan rumusan masalah lainnya (Wekke, 2019).

Selalu gunakan perspektif interdisipliner atau multidisplin. Sebagai contoh lingkungan dan pendidikan (Desi, Sabri, Karim, Gonibala, \& Wekke, 2021).

\section{Studi Kasus}

Penelitian-penelitian berikut ini merupakan penelitian di bangku pasca sarjana. Bukan pasca sarjana UIN atau IAIN, tetapi dari STAIN Sorong.

Sehingga tidak ada alasan bagi mahasiswa tidak meproduksi pengetahuan "baru".

Wekke, Siarni, \& Nuryantika (2016) mengkaji sekolah Islam terpadu. Sementara Wekke, Arif, Zubair, \& Wardi, (2019) membahas Muhammadiyah Papua. Adapun Wekke, Rubawati, \& Nurjannah (2016) membahas kepemimpinan transformatif di madrasah. 
Melalui awalnya studi naskah kemudian menjadi publikasi (Wekke, Siddin, \& Langputeh, 2019). Sementara observasi ini juga dari diskusi kelas terkait panti asuhan (Wahyuddin, Kasan, \& Wekke, 2018). Pesantren yang memasukkan unsur panti asuhan (Wekke, Siddin, \& Kasop, 2018). Begitu pula studi naskah dengan tema Inggris (Wekke \& Tang, 2016). Mangkoso (Wekke, Wihayuningtyas, Muntaha, \& Mukhlis, 2018).

Setelah itu, konversi tesis ke buku (Wihayuningtyas, Amin, \& Wekke, 2021). Bahkan ini dari kuliah strata satu (Wekke, Ruaidah, \& Wardi, 2019).

LATIHAN: pertama, mulailah dengan mengenali postur penelitian; kedua, dilanjutkan dengan melihat sebuah fenomena; ketiga, diteruskan dengan mengkonfirmasi literatur.

\section{Penutup}

Penelitian, boleh jadi bukan sebuah ide yang sempurna. Setidaknya dimulai terlebih dahulu. Kemudian dapat disempurnakan dari waktu ke waktu. Sehingga bisa menjadi sebuah publikasi yang "utuh".

Satu pesan khusus, tidak boleh berkecil hati berada di tanah Papua. Bahkan bolehjadi, saudarasaudari memiliki keunggulan komparatif berbanding dengan mahasiswa/mahasiswi pasca di perguruan tinggi lain di pelbagai belahan dunia.

\section{Daftar Pustaka}

Abdullah, M. A. (1996). Studi agama: normativitas atau historisitas?. Pustaka Pelajar.

Desi, N., Sabri, M., Karim, A., Gonibala, R., \& Wekke, I. S. (2021). Environmental Conservation Education: Theory, Model, and Practice. Psychology and Education Journal, 58(3), 11491162.

Madjid, N. (1992). Islam: Doktrin dan Peradaban. Jakarta: Yayasan Wakaf Paramadina.

Mathar, M. (2007). Kimiawi Pemikiran Islam: Arus Utama Islam di Masa Depan. Makassar: Universitas Islam Negeri Alauddin Makassar.

Mudzhar, A. (1998). Pendekatan studi islam: dalam teori dan praktek. Yogyakarta: Pustaka Pelajar.

Wahyuddin, W., Kasan, W., \& Wekke, I. S. (2018). Pembinaan Aqidah di Panti Asuhan Minoritas Muslim. https://doi.org/10.31227/osf.io/j5bq4.

Wekke, I. S. (2018). Masa Depan Kajian Islam di Indonesia. https://doi.org/10.31227/osf.io/36tua.

Wekke, I. S. (2019). Mengindentifikasi Masalah Penelitian. Metode Penelitian Ekonomi Syariah. Yogyakarta: Gawe Buku.

Wekke, I. S. (2020). Meneliti Islam: Pada Aspek Mana?. https://doi.org/10.31219/osf.io/tpmes.

Wekke, I. S., \& Tang, A. (2016). Kultur Pendidikan Islam Di Minoritas Muslim Inggris. THAQAFIYYAT: Jurnal Bahasa, Peradaban Dan Informasi Islam, 17(1), 70-83.

Wekke, I. S., Arif, B., Zubair, A., \& Wardi, M. (2019). The Role of Muhammadiyah Institution Towards Muslim Minority in West Papua. Jurnal Ilmiah Peuradeun, 7(1), 21-42.

Wekke, I. S., Rubawati, E., \& Nurjannah, S. (2017). Kepemimpinan Transformatif di Madrasah Minoritas Muslim Papua Barat. J-MPI (Jurnal Manajemen Pendidikan Islam), 2(1), 1-10.

Wekke, I. S., Siarni, S., \& Nuryantika, N. (2016). Kepemimpinan Sekolah Islam Terpadu di Minoritas Muslim Papua Barat. Akademika: Jurnal Keagamaan Dan Pendidikan, 12(2), 39. 
Wekke, I. S., Siddin, S., \& Kasop, I. (2018). Pesantren, Madrasah, Sekolah, Dan Panti Asuhan: Potret Lembaga Pendidikan Islam Minoritas Muslim. At-Tajdid: Jurnal Ilmu Tarbiyah, 6(1), 128-144.

Wekke, I. S., Siddin, S., \& Langputeh, S. (2019). Islamic Education in Thailand Pattani Muslim Minority: What are the Institutional Continuity and Change?. Tadris: Jurnal Keguruan dan Ilmu Tarbiyah, 4(1), 127-134.

Wekke, I. S., Wihayuningtyas, N., Muntaha, P. Z., \& Mukhlis, M. (2018). Leadership Typology of Traditional Islamic Boarding School in Eastern Indonesia: Learning to Lead from DDI Mangkoso. INFERENSI: Jurnal Penelitian Sosial Keagamaan, 12(2), 331-348.

Wihayuningtyas, N., Amin, S., \& Wekke, I. S. (2021). Kepemimpinan dalam Memperjuangkan Pendidikan Bagi Minoritas Muslim Papua. Yogyakarta: Bintang Pustaka Madani. 